Brazilian Journal

of Chemical

\title{
MAINTENANCE OF PENICILLIN G ACYLASE EXPRESSION BY B. megaterium: PRESERVATION METHODS AND ACTIVITY RECOVERY
}

\author{
L. M. Pinotti", R. G. Silva, T. C. Zangirolami and R. L. C. Giordano \\ Departamento de Engenharia Química, Universidade Federal de São Carlos, \\ Phone: +(55) (16) 3351 8707, Fax: +(55) (16) 3351-8266, \\ C.P. 676, CEP 13565-905, São Carlos - SP, Brazil. \\ E-mail: plmp@iris.ufscar.br
}

(Received: December 27, 2005 ; Accepted: January 10, 2007)

\begin{abstract}
This work reports the influence of different culture preservation methods on the production of penicillin G acylase (PGA) by Bacillus megaterium ATCC 14945. The initial stock culture, presenting PGA activity of $97 \mathrm{IU} \mathrm{l}^{-1}$, was preserved for two years using different procedures: monthly subculturing and storage in refrigerator (S), freeze-drying using skim milk $10 \%$, plus inositol $5 \%$ as cryoprotectors (L1), freeze-drying using sucrose $7 \%$, plus peptone $7 \%$ (L2), and freezing with glycerol $10 \%$ (F). After cultivations at standard operational conditions, different values of enzyme activity were obtained: $56 \mathrm{IU} \mathrm{l}^{-1}$ for monthly subculturing (S), 15-41 IU l-1 for freeze-dried cells and frozen spores. All the tested methods have failed in preserving the PGA expression. Among all tested cultures, $\mathrm{S}$ presented the highest specific activity, and was used to prepare a standard inoculum in cryovials $\left(-50^{\circ} \mathrm{C}\right.$, frozen spores in a $20 \%$ glycerol solution). By cultivation of this inoculum under different conditions, it was found that PGA activity raised to $128 \mathrm{IU} \mathrm{l}^{-1}$ when $0.4 \mathrm{~g} \mathrm{l}^{-1}$ of salts was added to the medium.

Keywords: B. megaterium; Cryovials; Cryoprotectors; Penicillin G Acylase; Preservation methods.
\end{abstract}

\section{INTRODUCTION}

Penicillin G acylase - PGA (E.C.3.5.1.11) is an important commercial enzyme used for hydrolysis of penicillin $\mathrm{G}$, to produce 6 aminopenicillanic acid (6APA). 6-APA is a key compound in the industrial production of semi-synthetic $\beta$-lactam antibiotics such as amoxycillin and ampicillin. $\beta$-lactam derived drugs have the greater share in the world market of antibiotics. From the total amount produced worldwide (about $5 \times 10^{7} \mathrm{~kg} /$ year), the group of $\beta$ lactam antibiotics contributes with $3 \times 10^{7} \mathrm{~kg} /$ year (Arroyo et al.,2003).

Many microorganisms synthesize PGA: Escherichia coli, Proteus ruigeri and Bacillus megaterium are among the most studied ones
(Ospina,1992). Most works reported by the literature have focused on the intracellular enzyme obtained from Escherichia coli (Balasingham et al.,1972; Alvaro et al.,1990; Guan et al.,1992; Robas et al.,1993). However, Bacillus megaterium is one of the few microorganisms that secrete the enzyme, and this property simplifies purification procedures, hence reducing downstream costs.

PGA synthesis by $B$. megaterium requires phenyl acetic acid (PAA) as inducer. However, at high concentrations it may inhibit enzyme production (Acevedo and Cooney,1973; Shewale and Sivaraman, 1989; Gentina et al.,1997). Another factor that influences enzyme production is the carbon source: glucose acts as a repressor of penicillin G acylase synthesis (Savidge, 1984; Illanes

*To whom correspondence should be addressed 
et al.,1994, Pinotti et al.,2000). Optimum growth conditions for $B$. megaterium are $28-35^{\circ} \mathrm{C}$ and $\mathrm{pH}$ 7.0-8.5 (Murao et al., 1964).

In the biochemical industry, strain instability and loss of productivity are common problems, yet seldomly addressed by the literature. Due to the dynamics of cell propagation under different storage conditions and periods, the microbial population might be subject to mutations caused by several factors (Azevedo, 1985) and the choice of the preservation method is crucial for a successful maintenance of the original culture characteristics (Costa and Ferreira, 1991).

Kilikian et al. (1992) reported that cultures of Aspergillus awamori stored in soil showed a decrease of glucoamylase productivity after 3 years of batch assays, even though the microorganism growth characteristics were preserved. Moyson and Verachtert (1993) reported high losses of lignin peroxidase (LiP) productivity after subsequent subculturing, and storage of the inoculum of Phanerochaete-chrysosporium on the maintenance medium at $4^{\circ} \mathrm{C}$, although better than subculturing, it was not advisable either. After long storage periods (50-70 weeks) at $4^{\circ} \mathrm{C}$, LiP production could not be reactivated in "poor" media (containing low amounts of vitamins and trace elements).

Santos et al. (2002) studied the influence of culture preservation methods and cultivation conditions on the production of the mycotoxins patulin and citrinin by Penicillium expansum. The authors concluded that cultivation conditions, preservation procedures and the storage period might affect strain performance. Hubalek (2003) reviewed the cryopreservation of microorganisms: many compounds may be employed as cryoprotector additives (CPAs), but only a few have been widely used with satisfactory results. Among them are: dimethylsulfoxide, glycerol, blood serum or serum albumin, skimmed milk, peptone, yeast extract, saccharose, glucose, methanol, polyvinylpyrrolidone, sorbitol, and malt extract.

Hence, it is clear that the maintenance for a desired characteristic of the microorganism deserves special attention. The preservation of PGA productivity in cultures of $B$. megaterium ATCC 14945 is the goal of this work. Different culture preservation methods were tested. Furthermore, the effects of the addition of salts to the cultivation medium, as well as the influence of changes in $\mathrm{pH}$ on the level of PGA production were analyzed.

\section{MATERIAL AND METHODS}

\section{Materials}

Cheese whey (Sigma), casein (Riedel), Alcalase (kindly donated by Novo Nordisk A/S), phenyl acetic acid, PAA (Carlo Erba), calcium carbonate (Synth), gelatin (Sadia) and penicillin G (Paraquímica).

\section{Microorganism}

B. megaterium ATCC 14945 from Tropical Foundation - Campinas, São Paulo, Brazil.

\section{Methods}

\section{Preparation of the Inoculum}

The inoculum was cultivated in erlenmeyers containing the following germination medium: enzyme-hydrolyzed casein $\left(40.0 \mathrm{~g} \mathrm{l}^{-1}\right)$, cheese whey $\left(7.0 \mathrm{~g} \mathrm{l}^{-1}\right)$ and $0.5 \mathrm{ml} \mathrm{l}^{-1}$ of antifoam (Berazaín et al., 1998). $3 \mathrm{ml}$ of the spores suspension, in a cryovial or in agar slants (culture monthly subculturing), were transferred to an erlenmeyer containing $75 \mathrm{ml}$ of germination medium. Germination and propagation occurred in a shaker at $300 \mathrm{rpm}$ and $30^{\circ} \mathrm{C}$, for 24 hours (Pinotti et al., 2002).

\section{Enzyme Production Medium}

PGA was produced in a medium which contained enzyme-hydrolyzed casein $\left(51.30 \mathrm{~g} \mathrm{l}^{-1}\right)$, cheese whey $\left(19.60 \mathrm{~g} \mathrm{l}^{-1}\right)$, calcium carbonate $\left(4.10 \mathrm{~g} \mathrm{l}^{-1}\right)$, phenyl acetic acid $\left(2.7 \mathrm{~g} \mathrm{l}^{-1}\right)$ and antifoam $\left(0.025 \mathrm{~g} \mathrm{l}^{-1}\right)$ (Berazaín et al., 1998). The initial pH was adjusted to 8.3 , except in the assays used to study the influence of $\mathrm{pH}$. The salt solution added to the medium, in some experiments, was $\left(\mathrm{mg}^{-1}\right)$ : $\mathrm{MgCl}_{2} .6 \mathrm{H}_{2} \mathrm{O}$ (75.3), $\mathrm{CaCl}_{2} .6 \mathrm{H}_{2} \mathrm{O}$ (55.1) $\mathrm{Na}_{2} \mathrm{SO}_{4}$ (53.3), $\mathrm{FeCl}_{3} .6 \mathrm{H}_{2} \mathrm{O}$ (14.5), $\mathrm{CoCl}_{2} \cdot 6 \mathrm{H}_{2} \mathrm{O}$ (1.21), $\mathrm{MnCl}_{2} .4 \mathrm{H}_{2} \mathrm{O} \quad(1.07), \quad \mathrm{CuCl}_{2} .2 \mathrm{H}_{2} \mathrm{O} \quad(0.8)$, $\mathrm{Na}_{2} \mathrm{MoO}_{4} .2 \mathrm{H}_{2} \mathrm{O}(0.68)$ and $\mathrm{ZnCl}_{2}(0.063)$ (Illanes et al.,1994). Shake incubators were used at 300 rpm and $30^{\circ} \mathrm{C}$ for 72 hours. The experiments started after transferring $10 \mathrm{ml}$ of inoculum to $100 \mathrm{ml}$ of enzyme-production medium. After eight hours, PAA was added. During the cultivation, samples were withdrawn every 24 hours and centrifuged at 14000 g, $4{ }^{\circ} \mathrm{C}$ for 20 minutes (Hojo and Hokka, 1996). The collected precipitate was dried for cell concentration analysis. PGA and the proteolytic activities were determined in the supernatant fraction. 


\section{Casein Hydrolysis}

Hydrolysis of $8 \%$ casein was carried out batchwise in a Metrohn pHstat, model Titrino, using a $0.5 \mathrm{M} \mathrm{NaOH}$ solution for $\mathrm{pH}$ control. The hydrolysis was carried out by the enzyme Alcalase ${ }^{\circledR}$ $0.6 \mathrm{~L}$ at the optimum conditions recommended by Novo Nordisk $\mathrm{A} / \mathrm{S} \quad\left(50^{\circ} \mathrm{C}\right.$ and $\left.\mathrm{pH} \quad 8\right)$. The enzyme/casein mass ratio was $1 / 50$.

\section{Preservation Methods}

The initial stock culture, presenting PGA activity of $97 \mathrm{IU} \mathrm{l}^{-1}$, had been preserved for two years using the following procedures: monthly subculturing and storage in refrigerator (S), freeze-drying using skim milk $10 \%$ plus inositol $5 \%$ as cryoprotectors (L1), freeze-drying using sucrose $7 \%$ plus peptone $7 \%$ (L2), and freezing with glycerol $10 \%(\mathrm{~F})$.

\section{Preparation of Frozen Spore Suspensions for Inoculum Standard}

B. megaterium (S culture) was transferred to agar slants and incubated $\left(7\right.$ days at $\left.30^{\circ} \mathrm{C}\right)$. The solid medium contained $3.0 \mathrm{~g} / \mathrm{l}$ of meat extract, $5.0 \mathrm{~g} / \mathrm{l}$ of peptone, $1.5 \mathrm{~g} / \mathrm{l}$ of glucose and $20.0 \mathrm{~g} / \mathrm{l}$ of agar. After harvesting with $0.9 \%$ saline solution and transferring to Roux flasks, the $B$. megaterium continued incubated for 7 additional days, at $30^{\circ} \mathrm{C}$. Then, a sterile cryoprotector solution containing $20 \%$ glycerol was added to the Roux flasks. Intense agitation and scraping of the agar surface allowed the release of the spores from the agar slants and the Roux flasks. The final step was adding aliquots of spores at the desired concentration $\left(10^{8}\right.$ spores $\left.\mathrm{ml}^{-1}\right)$ to sterile vials and stocking at $-50^{\circ} \mathrm{C}$. The spores were counted in a Neubauer camera using an optical microscope.

\section{Analytical Methods}

\section{PGA Activity}

The enzyme activity was determined via hydrolysis of penicillin $\mathrm{G} 0.2 \mathrm{M}, \mathrm{pH} 8$ (phosphate buffer $10 \mathrm{mM}$ ) and $37{ }^{\circ} \mathrm{C}$. The produced 6-APA reacted with p-dimethylaminobenzaldehyde (PDAB) (Balasingham et al., 1972), and measured at $415 \mathrm{~nm}$. One international unity (IU) is the amount of enzyme that catalyses the formation of $1 \mu \mathrm{mol}$ of 6 -APA from penicillin $\mathrm{G}$ in one min. for these conditions.

\section{Protease Detection}

The fermentation broth in different dilutions was mixed with concentrated gelatin solution, maintained at $40^{\circ} \mathrm{C}$ for $1 \mathrm{~h}$ and then stored in the refrigerator. The non-jellification of the final solution indicated the presence of proteases in the medium.

\section{RESULTS AND DISCUSSION}

\section{a) Influence of Preservation Methods on the Growth of Bacillus megaterium and on PGA Production}

Figure 1a presents the results of penicillin $G$ acylase production, obtained after the cultivation of cultures of $B$. megaterium ATCC 14945 preserved using the previously described methods. All the tested methods resulted in a reduced activity when compared to the initial stock culture, $97 \mathrm{IU}^{-1}$ (Pinotti et al., 2000). The experiment with the subcultured microorganism (S) presented the best results, $57 \mathrm{IU} \mathrm{1}^{-1}$ of PGA. The same behavior had already been reported by some authors (Moyson and Verachtert, 1993; StimHerndon et al.,1996). However, cultures preserved in the form of freezedried cells or frozen spores (cultures L1, L2 and F Figure 1), which were considered reliable methods for storage (Krasil'nikova and Zakharchuk, 2000), exhibited even smaller PGA productivity. The nature and concentration of the cryoprotectors, as well the preservation time, may be important for the microorganism conservation. A similar conclusion was obtained by Hubalek, 2003, after an extensive review of protectors to be used in the cryopreservation of microorganisms. This author reports that the best CPA (cryoprotector additives), or combination of CPAs, and the optimum concentration for preservation of a particular microorganism has to be determined empirically.

The obtained results showed that none of the cryoprotectors were effective in preserving the production characteristics of the microorganism during a 2-year period - at least, for the concentrations tested at this stage. Duplicates of the assays with the culture $\mathrm{S}$ confirmed these results. The standard deviation was $\pm 10 \%$ for both cell mass and PGA activity, confirming previous results by Pinotti et al. (2002). Figure 1b presents these results for cell growth.

The culture L1, which was preserved through the use of skim milk $10 \%$ and inositol $5 \%$, besides demonstrating slow growth (Figure 1b), was visually different from the others, exhibiting smaller chains of cells when examined under the microscope. The results from Figure $1 \mathrm{~b}$ and Table 1 showed that, though the frozen culture using glycerol $10 \%$ (culture F) had the highest value for cell concentration, it provided the lowest specific activity. It can also be observed that the highest specific PGA production was achieved using the culture S (monthly subculturing). One possible explanation for the reduction of PGA activity is the presence of two or more colonies with different enzyme production capacities in the same culture. These different colonies might have appeared due to either mutation or contamination. Culture $\mathrm{S}$ was used to perform purity studies hereafter. 


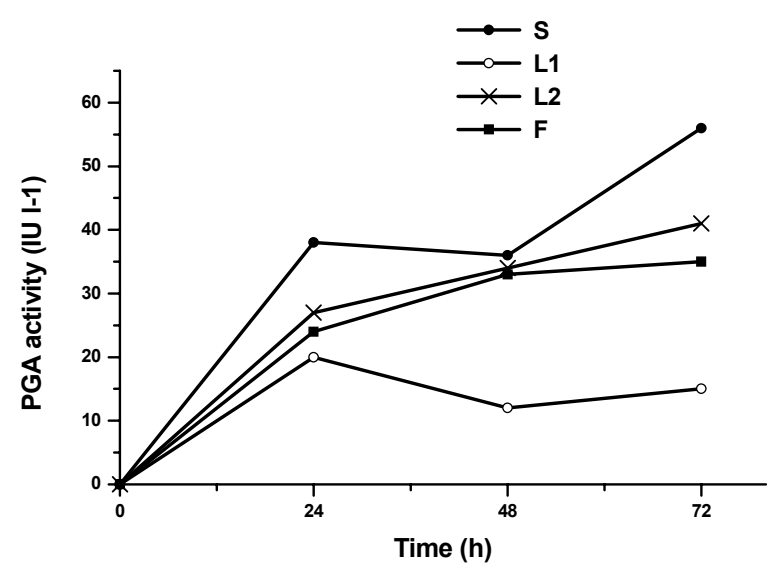

(a)

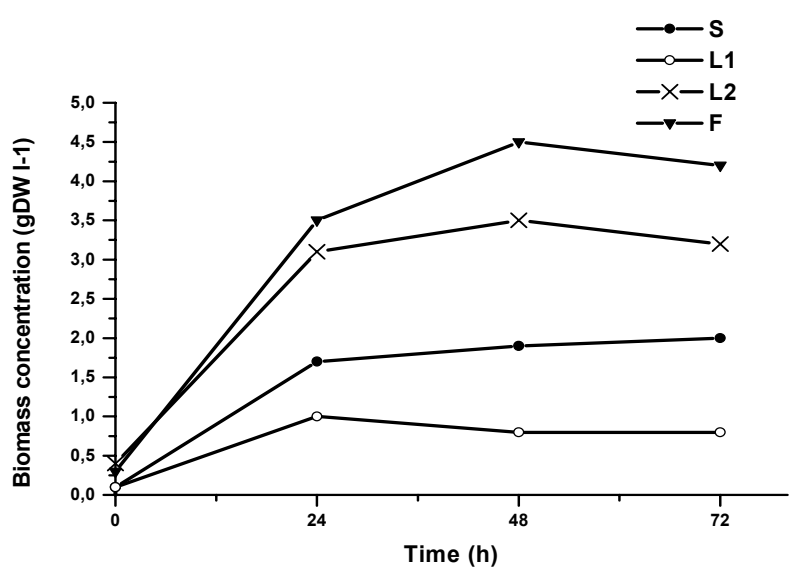

(b)

Figure 1: (a) PGA activity (IU $1^{-1}$ ) and (b) biomass concentration (g DW $1^{-1}$ ) in cultivations of $B$. megaterium ATCC 14945 using the fermentation medium proposed by Berazain et al. (1998). Cultures preserved by different methodologies: $\mathrm{S}=$ slant stored in refrigerator with subculturing; $\mathrm{L} 1$ and L2 = freeze-dried cells using skim milk 10\% plus inositol 5\% and sucrose $7 \%$ plus inositol $7 \%$, respectively, as cryoprotectors; $\mathrm{F}=$ cryovial preserved at $-50^{\circ} \mathrm{C}$ using glycerol $10 \%$.

Table 1: Calculated values of specific activity for PGA production experiments using cultures of the same strain of Bacillus megaterium ATCC 14945, preserved by different methodologies

\begin{tabular}{|l|c|}
\hline Culture & $\begin{array}{c}\text { Specific Activity } \\
\text { (IU/g cells) }\end{array}$ \\
\hline S (monthly subculturing) & 27.27 \\
L1 ( freeze-drying using skim milk 10\% plus inositol 5\%) & 18.75 \\
L2 (freeze-drying using sucrose 7\% plus peptone 7\%) & 12.66 \\
F (freezing with glycerol 10\%) & 8.54 \\
\hline
\end{tabular}

\section{b) Culture Purity}

Culture $\mathrm{S}$ was cultivated in the germination liquid medium, from where samples were taken, diluted, and incubated in solid medium. Macroscopically, the arising of two colonies was observed, apparently different, denominated A and B. Colony A presented a denser, more concentrated aspect, while colony B showed a less dense, and more disperse form.

Both of these colonies were harvested from the plates and separately transferred to new slants. After incubation in the slants, colonies $\mathrm{A}$ and $\mathrm{B}$ were separately cultivated in liquid medium of germination and afterwards used in experiments to evaluate their enzyme productivity. The values obtained for the maximum specific growth rate $\left(0.2 \mathrm{~h}^{1}\right.$ for colony $\mathrm{A}$ and $0.03 \mathrm{~h}^{-1}$ for colony $\left.\mathrm{B}\right)$ showed that both of these colonies are indeed formed by different cells. The results obtained in the production experiments (Figure 2) showed that both colonies reached the same (small) PGA activity. The decrease of the enzyme production can be due to a degeneration of the microbial population, caused by successive subculturing throughout two years. Another possible explanation could be the excretion of extra-cellular proteases simultaneous to PGA. The presence of proteases in the fermentation broth was then investigated. The methodology was very sensitive to the presence of proteases in the medium, but jellification of the solution was noticed, indicating that there were no proteases in the medium. Studies to recover the initial PGAproducing ability were then undertaken, using culture $\mathrm{S}$. 


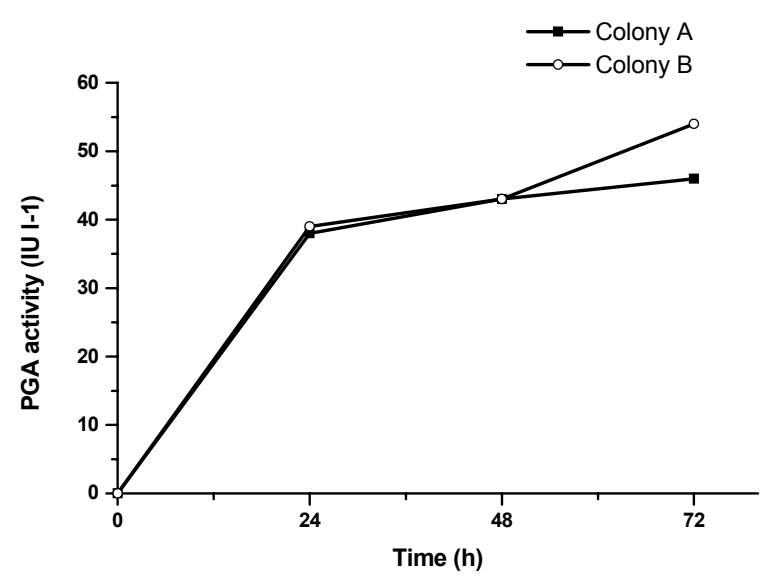

(a)

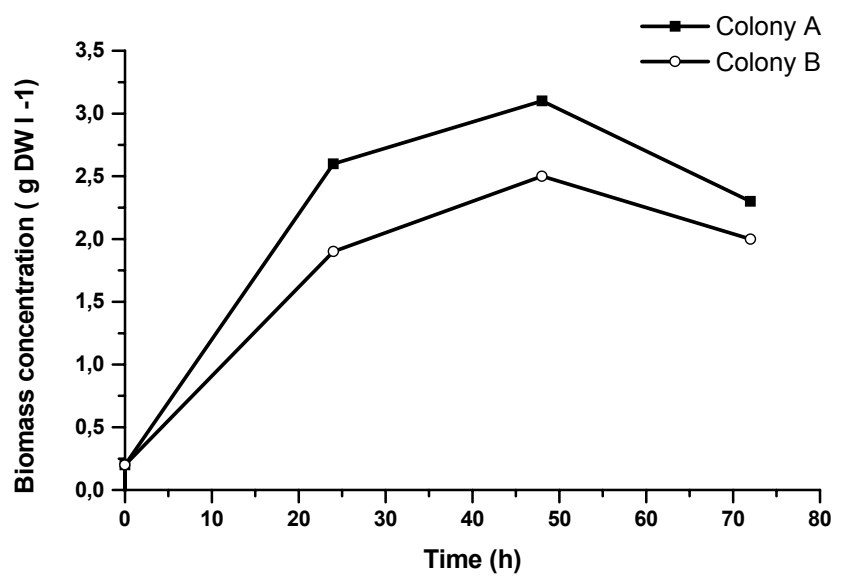

(b)

Figure 2: PGA production (a) and biomass formation (b) in cultivations carried out with colonies A and B isolated from culture $\mathrm{S}$.

\section{c) Culture Reactivation: Influence of $\mathrm{pH}$ and Medium Supplementation on PGA Production}

From the values calculated for the specific enzyme activity, in experiments using culture preserved by different methods (Table 1), the $\mathrm{S}$ culture (monthly subculturing) was selected to proceed studies aiming at restoring the PGA production.

The first step was to prepare cryovials with the selected culture in order to have a standard inoculum for the reactivation experiments. Although culture $\mathrm{F}$ (frozen spores in $10 \%$ glycerol, $-50^{\circ} \mathrm{C}$ ) showed a loss of productivity after two years, it was decided to use this method for our stock culture preservation, but increasing the cryoprotector concentration $(20 \%$ glycerol). This method has been largely employed for culture preservation and facilitates further studies by keeping the same volume of a culture with the same characteristics in each cryovial.

Two strategies were used: changing the initial $\mathrm{pH}$ of the medium and adding salts to the medium. Two experiments were made where the fermentation

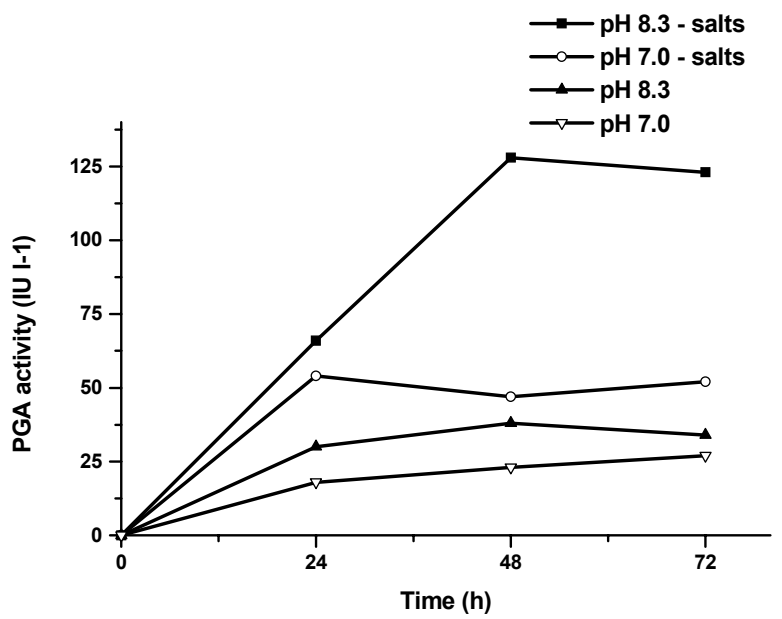

(a) medium was supplemented with salts and the initial $\mathrm{pH}$ was set to 8.3 (the same value used previously) and 7. The other 2 experiments were also run setting the initial $\mathrm{pH}$ value to 8.3 and 7.0. However, the fermentation medium was not supplemented with salts.

The results obtained in these experiments (Figure 3 ) clearly illustrate the importance of adding salts for the reactivation of the culture. The medium supplemented with salts and $\mathrm{pH}$ set to 8.3 resulted in approximately 3 times more enzymatic activity than the medium not supplemented with salts and $\mathrm{pH}$ set to 8.3. The $\mathrm{pH}$ also showed to be an important variable. However, changing the initial $\mathrm{pH}$ to $7.0 \mathrm{did}$ not improve the enzyme production. On the contrary, the enzymatic activity fell to one-half of the one that was obtained when the initial $\mathrm{pH}$ was adjusted to 8.3, in the presence of salts. This effect was not observed for experiments in which the medium was not supplemented with salts. In this case, the cells might have been affected by nutrients (salts) deficiency, which hindered the improvement in PGA production for higher initial $\mathrm{pH}$.

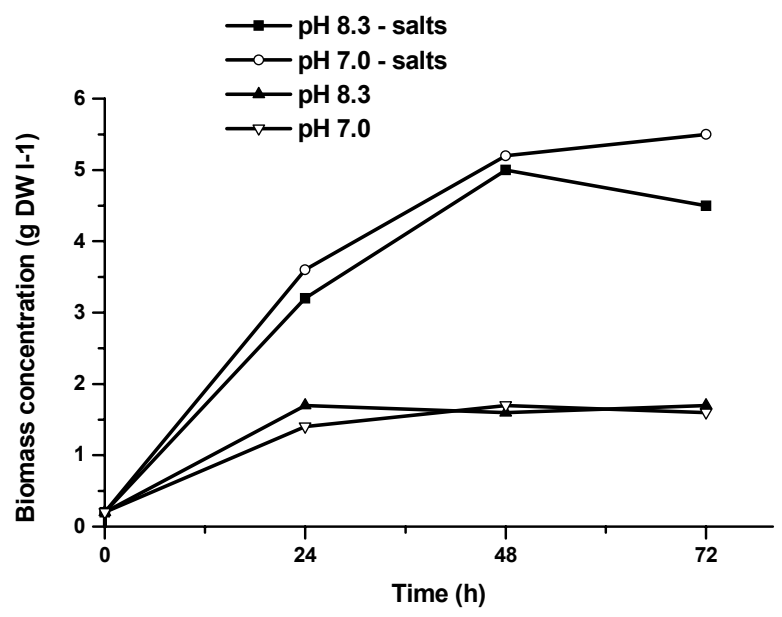

(b)

Figure 3: Results obtained for PGA production (a) and biomass formation (b) by the selected stock culture $(\mathrm{S})$, grown in fermentation medium supplemented or not with salts under different initial pHs. 
The increase in PGA production due to salts addition evoked interest to investigate the effect of this addition on the frozen culture using glycerol $10 \%$ (culture F). This culture showed the highest cell concentration, but the lowest specific activity. Therefore, the next experiment performed with culture $\mathrm{F}$, aimed at verifying whether salts deficiency was the cause for the low enzyme productivity. However, culture $\mathrm{F}$ did not exhibit any PGA production (data not shown), even in the presence of salts. Since the addition of mineral salts to the cultivation medium resulted in a rather significant improvement in PGA production, the influence of

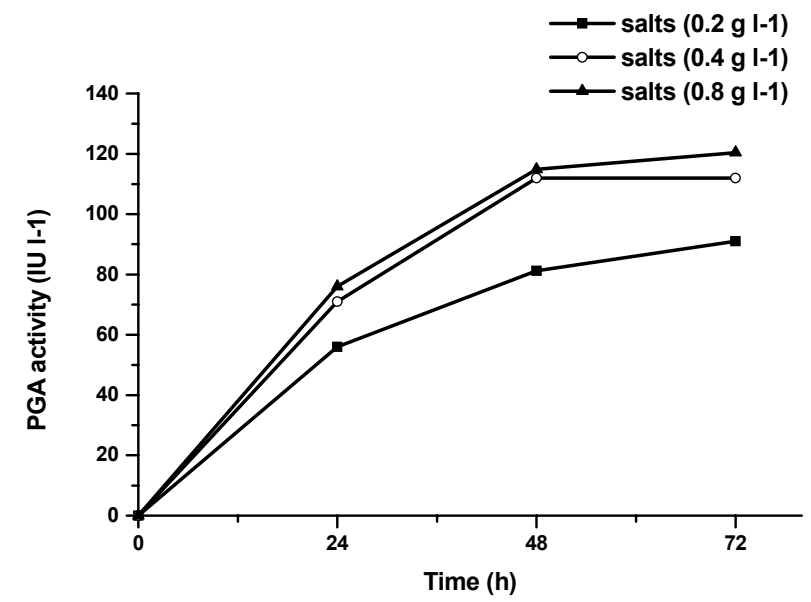

(a) the salts concentration was then studied, in three suplementary experiments, with salt concentrations in the fermentation medium of $0.2,0.4$ and $0.8 \mathrm{~g} \mathrm{l}^{-1}$, respectively. In previous experiments with salts addition, a concentration of $0.2 \mathrm{~g} \mathrm{l}^{-1}$ was always employed.

The results of these experiments, presented in Figure 4, indicate that an increase in the concentration of salts led to an improvement in PGA production. The fermentation medium containing 0.4 $\mathrm{g} \mathrm{l}^{-1}$ salts seemed to be the best choice, since enzyme activity remained practically the same when the concentration of salts was enhanced to $0.8 \mathrm{~g} \mathrm{l}^{-1}$.

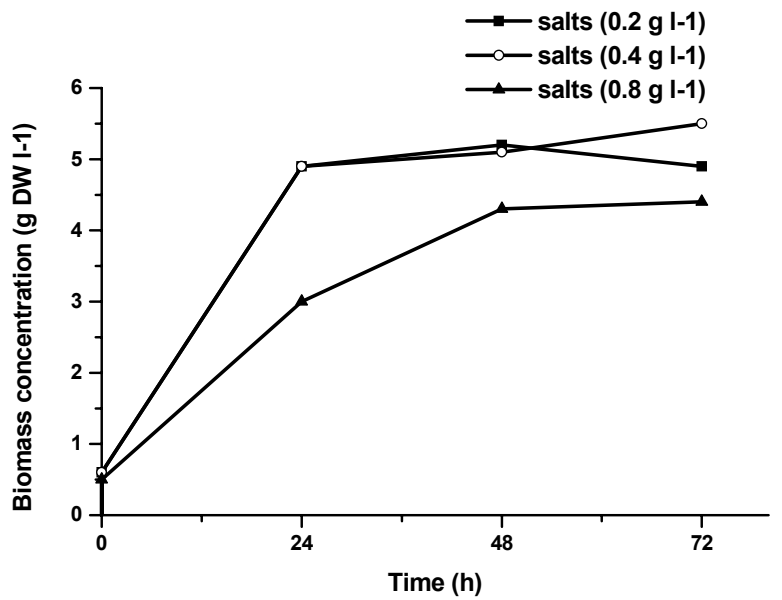

(b)

Figure 4: PGA production (a) and biomass formation (b) by the selected stock culture using different concentrations of salts (initial $\mathrm{pH} 8.3$ ).

\section{CONCLUSIONS}

Some important conclusions were obtained with this work. The results confirmed, for instance, that preservation of the characteristics of microorganisms during long periods is not straightforward. Cultures stored during long periods, submitted or not to successive subculturing and/or preserved inadequate, can undergo mutations and present a considerable decrease in productivity, hence jeopardizing studies involving other variables. Nature and concentration of the cryoprotectors, as well the preservation time, may be important for the microorganism conservation.

The addition of mineral salts to the cultivation medium considerably increased the PGA production. The optimum salts concentration was $0.4 \mathrm{~g} \mathrm{l}^{-1}$. The medium initial $\mathrm{pH}$ is also an important variable for the enzyme production. In this work, changing the usual $\mathrm{pH}$ value, 8.3 , to 7.0 led to a lower enzyme productivity.

\section{ACKNOWLEDGEMENTS}

The authors wish to thank FAPESP, the researchfunding agency of the State of São Paulo, Brazil.

\section{REFERENCES}

Acevedo, F. and Cooney, C.L. Penicillin Amidase Production by Bacillus megaterium. Biotechnol. Bioeng. 15, 493-503 (1973).

Alvaro, G., Fernandez-Lafuente, R., Blanco, R.M. and Guisàn, J.M. Imobilization - Stabilization of Penicillin G Acylase from Escherichia coli. Appl. Biochem. Biotechnol. 181-195 (1990).

Arroyo, M., de la Mata, L., Acebal, C. and Pilar Castillon, M. Biotechnological Applications of Penicillin Acylases: State of the Art. Appl. Microbiol. Biotechnol. 60, 507-514 (2003).

Azevedo, J.L. Melhoramento Genético de Microrganismos e sua Aplicação à Hidrólise 
Enzimática de Biomassas. In Anais do II Seminário de "Hidrólise Enzimática de Biomassas" (II SHEB) 1, 93-106 (1985).

Balasingham, K., Warburton, D., Dunnil, P. and Lilly, D. The Isolation and Kinetics of Penicillin Amidase from Escherichia Coli. Biochim. Biophys Acta 276, 250-256 (1972).

Berazaín, J.G.H.Q., Hojo, O. and Hokka, C.O. Utilization of Cheese Whey for the Production of Penicillin G Acylase from Bacillus megaterium ATCC 14945. Proceedings of ESBES-2-2 ${ }^{\text {nd }}$ European Symposium on Biochemical Engineering Science 72-77 (1998).

Costa, C.P. and Ferreira, M.C. Preservation of Microorganism - A Review. Rev. Microbiol 22(3), 263-268 (1991).

Gentina, J.C., Acevedo, F. and Villagra, M.P. Short Communication: Effect of Complex Nitrogen Sources on the Production of Penicillin Acylase by Bacillus megaterium. World J. Microbiol Biotechnol 13, 127-128 (1997).

Guan, Y., Wu, X.Y., Treffry, T.E. and Lilley, T.H. Studies on the Isolation of Penicillin Acylase from Escherichia coli by Aqueous Two-Phase Partioning. Biotechnol. Bioeng. 40, 517-524 (1992).

Hojo, O., Hokka, C.O. Statistical Medium Optimization for the Production of Penicillin G Acylase from Bacillus megaterium. Braz. J. Chem. Eng. 13 (3), 130-140 (1996).

Hubalek, Z. Protectants used in the cryopreservation of microorganisms. Cryobiology 46(3), 205-229 (2003).

Illanes, A., Acevedo, F., Gentina, J.C., Reyes, I., Torres, R., Cartagena, O. and Ruiz, M.A. Production of Penicillin Acylase from Bacillus megaterium in Complex and Defined Media. Process Biochem. 29, 263-270 (1994).

Kilikian, B.V., Facciotti, M.C.R. and Schmidell, W. Analysis of the Kinetic Pattern of Glucoamylase Production Regarding the Aspergillus awamori Preservation Time. Ver. Microbiol. 23(2), 123127 (1992).

Krasil'nikova, E.N. and Zakharchuk, L.M. The Activity of the Carbon Metabolism Enzymes in
Chromatium Minutissimum After Long-Term Storage. Microbiology 69(3), 266-270 (2000).

Moyson, E. and Verachtert, H. Factors Influencing the Lignin-Peroxidase-Producing Ability of Phanerochaete-Chrysosporium. Appl. Microbiol. Biotechnol. 39(3), 391-394 (1993).

Murao, S., Sakaguchi, K. and Kono, K. Process for Preparing 6-Aminopenicilanic Acid by Bacillus megaterium. U.S. Patent 3, 144, 395 (1964).

Ospina, S. S. Characterization and Use of a Penicillin Acylase Biocatalyst. J. Chem. Tech. Biotechnol. 205-214 (1992).

Pinotti, L.M., Silva, A.F.S. Silva, R.G. and Giordano, R.L.C. Study of Different Media for Production of Penicillin G Acylase from Bacillus megaterium ATCC 14945. Appl. Biochem. Biotechnol. 84-86, 655-663 (2000).

Pinotti, L.M., Silva, R.G., Giordano, R.C. and Giordano, R.L.C. Inoculum Studies in Production of Penicillin G Acylase by Bacillus megaterium ATCC 14945. Appl. Biochem. Biotechnol. 98100, 679-686 (2002).

Robas, N., Zouheiry, H., Bralant, G. and Bralant, C. Improved Penicillin Amidase Production Using a Genetically Engineered Mutant of Escherichia coli ATCC 11105. Biotechnol. Bioeng. 41, 14-24 (1993).

Santos, I.M., Abrunhosa, L., Venâncio, A. and Lima, N. The Effect of Culture Preservation Techniques on Patulin e Citrinin Production by Penicillium expansum Link. Lett Appl. Microbiol 35, 272-275 (2002).

Savidge, T.A. Enzymatic Conversions used in the Production of Penicillins and Cephalosporins. In: Biotechnology of Industrial Antibiotics, edited by Vandame, E. J., Ed. Marcel Dekker (1984).

Shewale, J.G. and Sivaraman, H. Penicillin Acylase: Enzyme Production and its Application in the Manufacture of 6-APA. Process Biochem. 146154 (1989).

StimHerndon, K.P., Nair, R., Papoutsakis, E.T. and Bennett, G.N. Analysis of Degenerate Variants of Clostridium Acetobutylicum ATCC 824. Anaerobe 2(1), 11-18 (1996). 